\section{Dr L. DuBridge on Public Issues}

IT would be unreasonable to expect that Dr Lee DuBridge will be any more closely bound by his previous public utterances than any other holder of high office, but the following extracts from speeches and articles may serve to clarify his starting point.

\section{The Present Crisis}

June 19, 1968.

A great debate is now going on in this country as to whether it is not time to slow up on the support of science and engineering and to divert our resources to solving our other problems. I do not know how this debate will come out, and I do not even know what the right answer is. I do know that the very fact that there is a debate must cause scientists and engineers to re-examine their activities and their plans for the future. This may be a good thing for us to do, but the necessity of doing so is surely one element which adds to our troubles.

\section{Federal Research Support}

December 3, 1968.

I am not at all convinced that the federal government is so short of money that it can no longer afford the approximately 1.5 billion dollars a year which it has been investing in university education and research in the science and engineering fields. When we recall that our Gross National Product is rapidly approaching the trillion-dollar-a-year level, and when we recognize that it would have been impossible for our economy to zoom along at such a rapidly rising rate without science and engineering, and without trained scientists and engineers, we can realize that our investment in graduate education and research in our universities has paid off a hundred-fold. I think it can easily be established that, solely from the standpoint of economics and finance, the federal $\epsilon$ xpenditures in graduate education and research constitute one of our most valued national investments.

I believe a careful study will make it clear that our present level of expenditure for graduate education and research in science and engineering is none too large to maintain the viability of our present national programme in this field; and if we take into account the probable gradual rise in graduate student population and in the population of trained scientists and engineers available for university work, and take into account the rising needs of the country and the rising costs of education and research, that the nation should definitely plan to have the national budget for university work increased for the next few years at a rate of something like 10 to 12 per cont per year. I do not pretend that such a rate must be or could be continued for ever, for this is a rate higher than our rise in GNP or in federal income-and if one projects an exponential curve far enough, the rate of 10-per-cent-per-year increase would some day make our university research budget greater than our total federal tax income. However, our federal investment in university science and engineering is now such a small portion of the total budget that it is surely a good investment to increase that proportion at a reasonable rate for the next ten years or so.

\section{Government Machinery}

December 3, 1968.

I recognize that if we do this, we will also have to improve many of the parts of the machinery of government which allocate these funds in order to make sure that they are allocated effectively, and not through the use of pork barrel techniques. It is my under- standing that the new Administration will conduct a careful study of this situation.

Space Research

August 11, 1967.

Is the purpose of that programme to extend scientific knowledge, or to enhance national prestige, or to achieve other objectives? Obviously the space programme has many aims and objectives, and there is wide disagreement as to which ones take priority. Those who feel (wrongly) that the principal aim of Congress in supporting NASA is the advance of basic science contend (rightly) that $\$ 5$ billion a year could be more fruitfully expended in other ways. Those who believe that the principal objectives of the space programme are to enhance national prestige or to satisfy a human urge for exploration, or to assure future military or economic dividends argue that some or all of these objectives are being achieved and that the total result is worth $\$ 5$ billion a year. Others deny this. Clearly the question is not a scientific one; it is one of public policy. And those (in the Congress and the Executive branch) responsible for establishing public policy have decided that the expenditure is justified.

Scientists who insist that this $\$ 5$ billion could be more profitably expended for other scientific enterprises may be right, but they miss the point. The $\$ 5$ billion is not being spent primarily to advance science, any more than the $\$ 50$ billion expended by the Defense Department is. Yet, in both cases a moderate fraction of the budget is necessarily used to advance science.

However, it must be stressed that neither NASA nor any other agency charged with implementing a national-poliey goal is intended to be a philanthropic agency authorized to provide benefactions to university science departments.

If the government wishes (as I believe it should) to develop a more adequate and more balanced programme for strengthening American science then it should charge suitable agencies (principally the National Science Foundation) with this particular task, and provide funds adequate for carrying it out.

\section{Secrecy}

July 12, 1967.

An important part of a student's training is not only to do research but to discuss it openly with his colleagues throughout the scientific or scholarly world. Open, critical discussion is the final test of the validity and value of a research enterprise, and the student should experience this early.

\section{Summer Salaries}

$196 \%$.

A professor with a grant or contract may receive two or three months' extra pay for working on his research during the summer. His colleague across the hall or across the campus is doing equally significant scholarly work during the summer for no extra pay; or he may be unable to afford this luxury and desert his scholarly work to take a summer job elsewhere, and both he and the university suffer. Many committees and commissions studying this problem have advocated the abandonment of the obsolete policy of assuming that a university faculty momber normally works and should be paid for only nine months. But few universities have been able to find funds for a year-round salary plan for all. Until this problem is solved, it will be vexatious to every university programme, and to every government agency, too. 